\section{Benzodiazepines and pneumonia or aspiration pneumonitis}

Dr Obiora et $a l^{1}$ have presented some interesting data. One could quibble about the validity of the nested case-control model, but this issue is important mainly in identifying the fact that the patients were not individually assessed, nor were their particular variables, apart from the ones of interest, benzodiazepines and pneumonia, taken into consideration. Part of the randomness was accounted for by the use of conditional logistic regression but, as frequently happens, the authors appear not to have differentiated between pneumonitis and pneumonia, not surprisingly as they were dependent on diagnoses given by other physicians. These two terms are so frequently used as synonyms that it appears that few remember that they are very different entities. ${ }^{2}$ The authors mention the greater use of benzodiazepines in the elderly, and this is one group of greatest interest. ${ }^{3}$

Individuals at an advanced age, with diseases such as diabetes, Chronic Obstructive Pulmonary Disease, Parkinson disease and others, have a high incidence of gastroesophageal reflux (GER). Benzodiazepines are known to increase the risk of reflux being known, anecdotally, as 'muscle relaxants'. ${ }^{5}$ The lower oesophageal sphincter is not a true sphincter but an area of muscle with, normally, increased tone. When this tone is diminished, reflux results, most often during the deepest part of sleep, and is likely to be unwitnessed. Unless there has been massive aspiration of stomach contents, the patient may simply feel unwell for a day or so, may have a fever and malaise, and 4-5 days later, develop a bacterial pneumonia due to the normal inhalation of saliva which uses the original area of chemical damage as a base for infection. ${ }^{67}$ It is suggested that the use of benzodiazepines be very carefully considered in individuals known to suffer GER, to suffer a disease in which GER is common, or one in which immunodeficiency may be inferred. This is not to imply that the benzodiazepines themselves affect immune status, but that infection is likely to be more hazardous in such patients as a result of the above.

\section{Irene Campbell-Taylor}

Correspondence to Dr Irene Campbell-Taylor, 4303 New Waterford Highway, New Waterford NS B1H 2E1, Canada; drirenect@aol.com

\section{Competing interests None.}

Provenance and peer review Not commissioned; internally peer reviewed.

To cite Campbell-Taylor I. Thorax 2013;68:591.

Received 28 December 2012

Accepted 11 January 2013

Published Online First 31 January 2013

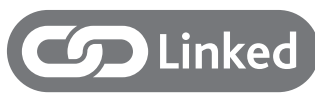

http://dx.doi.org/10.1136/thoraxjnl-2013-203233

Thorax 2013;68:591.

doi:10.1136/thoraxjnl-2012-203193

\section{REFERENCES}

1 Obiora $E$, Hubbard R, Sanders RD, et al. The impact of benzodiazepines on occurrence of pneumonia and mortality from pneumonia: a nested case-control and survival analysis in a population-based cohort. Thorax 2012;68:163-70.

2 Marik PE. Aspiration pneumonia and aspiration pneumonitis. N Engl J Med 2001;344:665-71.

3 Mylotte JM, Goodnough S, Naughton BJ. Pneumonia versus aspiration pneumonitis in nursing home residents: diagnosis and management. Am J Geriatr Soc 2003;51:17-23.

4 Fass R, Quan SF, O'Connor GT, et al. Predictors of heartburn during sleep in a large prospective cohort study. Chest 2005;127:1658-6.

5 Rushnak MJ, Leevy CM. Effect of diazepam on the lower esophageal sphincter. A double-blind controlled study. Am J Gastroenterol 1980;73:127-30.

6 Campbell-Taylor I. Aspiration pneumonia. N Engl J Med 2001;344:1869; discussion 1869-70 (with Marik, Finucane, Christmas.).

7 Gleeson J, Eggli D, Maxwell S. Quantitative aspiration during sleep in normal subjects. Chest 1997;111:1266-72. 